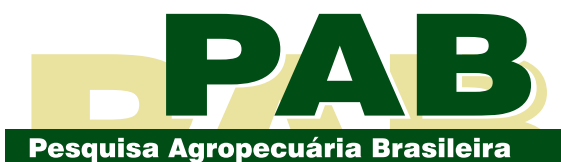

ISSN 1678-3921

Journal homepage: www.embrapa.br/pab

For manuscript submission and journal contents, access: www.scielo.br/pab

\section{Nitrogen, phosphorus, and potassium released by decomposition of palisade grass to soybean in succession}

\begin{abstract}
The objective of this work was to determine the nitrogen, phosphorus, and potassium released by $\mathrm{N}$-fertilized Urochloa brizantha straw, desiccated before sowing of no-tillage soybean (Glycine max) in succession. The pasture was grown in three paddocks, each fertilized with one $\mathrm{N}$ rate $\left(0,150\right.$, or $\left.300 \mathrm{~kg} \mathrm{ha}^{-1}\right)$, and assessed at two desiccation periods (60 or 15 days before soybean sowing), in four replicates. Nitrogen fertilization of $U$. brizantha pasture increases $\mathrm{N}$ and $\mathrm{K}$ cycling and the release of these nutrients to the subsequent soybean crop. The quantity of $\mathrm{K}$ released by $U$. brizantha straw fertilized with 150 or $300 \mathrm{~kg} \mathrm{ha}^{-1} \mathrm{~N}$ (about $80 \mathrm{~kg} \mathrm{ha}^{-1} \mathrm{~K}$ ) offsets that contained in an export of up to $4 \mathrm{Mg} \mathrm{ha}^{-1}$ soybean grains, assuming zero $\mathrm{K}$ losses in the system. An early desiccation of the U. brizantha pasture does not improve $\mathrm{K}$ uptake by the soybean crop, since $50 \%$ of the nutrient is released in the first 20 days after desiccation. The dynamics of P release from U. brizantha straw (about 6 to $10 \mathrm{~kg} \mathrm{ha}^{-1}$ during the soybean crop) is not influenced by $\mathrm{N}$ fertilization and the time of pasture desiccation.
\end{abstract}

Index terms: Urochloa brizantha, crop-livestock integration, grass desiccation times, pasture, straw residues.

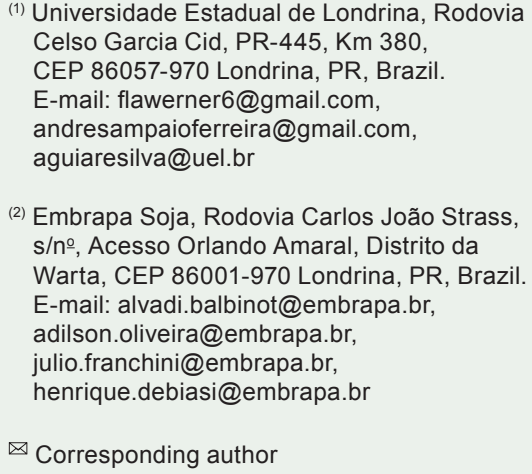

(2) Embrapa Soja, Rodovia Carlos João Strass, $\mathrm{s} / \mathrm{n}^{\circ}$, Acesso Orlando Amaral, Distrito da Warta, CEP 86001-970 Londrina, PR, Brazil. E-mail: alvadi.balbinot@embrapa.br, adilson.oliveira@embrapa.br julio.franchini@embrapa.br henrique.debiasi@embrapa.br

$凶$ Corresponding author

Received

March 10, 2020

Accepted

September 23, 2020

How to cite

WERNER, F.; FERREIRA, A.S.; BALBINOT JUNIOR, A.A.; OLIVEIRA JUNIOR, A. de; FRANCHINI, J.C.; DEBIASI, H.; SILVA, M.A. de A. e. Nitrogen, phosphorus, and potassium released by decomposition of palisade grass to soybean in succession. Pesquisa Agropecuária Brasileira, v.55, e01853, 2020. DOI: https://doi.org/10.1590/S1678-3921. pab2020.v55.01853.

\section{Nitrogênio, fósforo e potássio liberados pela decomposição da palhada de braquiária para a soja em sucessão}

Resumo - O objetivo deste trabalho foi avaliar o nitrogênio, o fósforo e o potássio liberados pela palha de pastagem de Urochloa brizantha adubadada com N, dessecada antes da semeadura da soja (Glycine max) em sucessão, no sistema plantio direto. A pastagem foi cultivada em três piquetes, cada um fertilizado com uma dose de $\mathrm{N}\left(0,150\right.$ ou $\left.300 \mathrm{~kg} \mathrm{ha}^{-1}\right)$, e avaliada em dois períodos de dessecação (60 ou 15 dias antes da semeadura da soja), com quatro repetições. A adubação nitrogenada na pastagem de U. brizantha aumenta a ciclagem de $\mathrm{N}$ e $\mathrm{K}$ e a liberação destes nutrientes à soja em sucessão. A quantidade de $\mathrm{K}$ liberada pela palha de $U$. brizantha adubada com 150 ou $300 \mathrm{~kg} \mathrm{ha}^{-1}$ de N (aproximadamente $80 \mathrm{~kg} \mathrm{ha}^{-1}$ de K) atende a exportação de até $4 \mathrm{Mg} \mathrm{ha}^{-1}$ de grãos de soja, ao se considerar a ausência de perdas de $\mathrm{K}$ no sistema. A dessecação antecipada de pastagem de $U$. brizantha não favorece o aproveitamento de K pela cultura da soja, já que $50 \%$ do nutriente é liberado nos 20 primeiros dias após a dessecação. A dinâmica de liberação de P pela palha de $U$. brizantha (de 6 a $10 \mathrm{~kg} \mathrm{ha}^{-1}$ durante a cultura da soja) não é influenciada pela adubação nitrogenada e pela época de dessecação.

Termos para indexação: Urochloa brizantha, integração lavoura-pecuária, épocas de dessecação de pastagem, pastagem, resíduo da palha. 


\section{Introduction}

The management of Crop-Livestock Integration Systems (ICLS) in a no-tillage (NT) system can increase the use efficiency of resources, as nutrients, to ensure high yields (Salton et al., 2014). To this end, ICLS is appropriate to increase the profitability and sustainability of soybean [Glycine max (L.) Merrill] yields in the tropical and subtropical regions of Brazil (Franchini et al., 2014).

The use of pasture of the genus Urochloa, integrated with grain production, is a feasible way of improving and sustaining NT systems in the long term (Costa et al., 2014). Forage species of this genus, apart from the high shoot and root biomass production, also favor a longer period of residue conservation on the soil, due to the high carbon/nitrogen ratio, which slows down decomposition and increases the suitability for hotter regions, where decomposition is fast (Franchini et al., 2014).

The cultivation of grain-producing crops after NT grass pastures can raise the $\mathrm{N}$ demand in the production system (Mateus et al., 2011). Thus, pasture fertilization with $\mathrm{N}$ is a technique that can increase yields of forages and subsequent crops (Costa et al., 2014). The $\mathrm{N}$ assimilated by forage plants is associated with carbon chains, intensifying the root and shoot growth, which can improve nutrient uptake and cycling, as $\mathrm{P}$ and $\mathrm{K}$ (Galindo et al., 2018). In turn, the nutrients released by the decomposing straw contribute to meet the nutritional needs of subsequent soybean (Cavalli et al., 2018).

Desiccation of plants present in the area by the application of non-selective herbicides is one of the main practices of NT systems. According to Franchini et al. (2014) the desiccation time can significantly change the nutrient availability for subsequent soybean, and Costa et al. (2015) suggested a synchronization of the nutrient release from residual straw with the requirement of subsequent annual crops. We hypothesize that nitrogen fertilization of the palisade grass pasture will increase the $\mathrm{N}, \mathrm{P}$, and $\mathrm{K}$ cycling, the decomposition rate of residual straw, and the release speed of these macronutrients to subsequent soybean, which may change the appropriate fertilization rates for the soybean crop.

In this context, the objective of this work was to determine nitrogen, phosphorus, and potassium released by nitrogen-fertilized Urochloa brizantha straw, desiccated at different times before no-till soybean sowing in succession.

\section{Materials and Methods}

The experiment was carried out between March 2016 and March 2018, in the municipality of Londrina, in the state of Paraná $\left(23^{\circ} 11^{\prime} \mathrm{S}, 51^{\circ} 11^{\prime} \mathrm{W}\right.$; at an altitude of $620 \mathrm{~m}$ ). The climate in the area, according to the Köppen-Geiger climate classification, is humid subtropical (Cfa), with an annual mean temperature of $21^{\circ} \mathrm{C}$, a mean maximum temperature of $28.5^{\circ} \mathrm{C}$ in February, and a mean minimum temperature of $13.3^{\circ} \mathrm{C}$ in July. The soil, with a very clayey texture, was classified as Latossolo Vermelho distroférrico in the Brazilian classification (Santos et al., 2018) or Rhodic Eutrudox in the USA classification (Soil Survey Staff, 2014) and had been cultivated with NT crops -, soybean in the summer and wheat (Triticum aestivum L.) or black oat (Avena strigosa Schreb.) in the winter -, for 15 years before this assay.

In March 2016, Urochloa brizantha 'BRS Piatã' (Syn. Brachiaria brizantha) was sown with $5 \mathrm{~kg} \mathrm{ha}^{-1}$ pure and viable seed in rows spaced $20 \mathrm{~cm}$ apart, intercropped with off-season corn (Zea mays L.). At pasture planting, the soil properties in the $0-20 \mathrm{~cm}$ layer were determined as follows: $27.9 \mathrm{~g} \mathrm{dm}^{-3}$ organic $\mathrm{C} ; \mathrm{pH}\left(\mathrm{CaCl}_{2}\right)$ 4.8; $15.5 \mathrm{mg} \mathrm{dm}{ }^{-3} \mathrm{P}$ (Mehlich-1); $207.2 \mathrm{mg} \mathrm{dm}^{-3}$ exchangeable $\mathrm{K} ; 641.3 \mathrm{mg} \mathrm{dm}^{-3}$ exchangeable $\mathrm{Ca} ; 170.2 \mathrm{mg} \mathrm{dm}^{-3}$ exchangeable $\mathrm{Mg}$; $15.3 \mathrm{mg} \mathrm{dm}^{-3} \mathrm{~S}, 1.3 \% \mathrm{Al}$ saturation, and $49 \%$ base saturation (medium fertility).

The experimental area was divided into three paddocks of approximately 1.2 ha. Each one was fertilized with a nitrogen rate $\left(0,150\right.$, and $\left.300 \mathrm{~kg} \mathrm{ha}^{-1} \mathrm{~N}\right)$ in the form of urea $(45 \% \mathrm{~N})$, by broadcast seeding, applying half the rate in September and the other half in November 2016. From October 2016 to July 2017, the area was grazed regularly and continuously by male cattle (live weight $350-550 \mathrm{~kg}$ ), maintaining a pasture height of $30 \mathrm{~cm}$. The mean stocking rate per paddock was 4 and $2 \mathrm{AU} \mathrm{ha}^{-1}$ (AU, animal unit $=450 \mathrm{~kg}$ live weight), respectively, in the plots with and without $\mathrm{N}$ fertilization. After the grazing period, the area was left ungrazed until August of the same year, when two desiccation times (60 and 15 days before soybean sowing - DBSS) were evaluated in each paddock, with four replications. After the desiccation period, the BRS 
1010 IPRO soybean cultivar was sowed in a $0.45 \mathrm{~m}$ row spacing and a seeding rate of 300 thousand plants per ha, fertilized with $350 \mathrm{~kg} \mathrm{ha}^{-1}$ of the commercial fertilizer formula 00-20-20 (N- $\left.\mathrm{P}_{2} \mathrm{O}_{5}-\mathrm{K}_{2} \mathrm{O}\right)$. The soybean seeds were inoculated with Bradyrhizobium elkaniibr in the day of sowing, according to technical recommendations.

The pasture was desiccated with glyphosate $\left(1,500 \mathrm{~g} \mathrm{ha}^{-1}\right.$ a.e. in a spray volume of $\left.200 \mathrm{~L} \mathrm{ha}^{-1}\right)$, applied with a tractor sprayer with fan-type spray tips. At both drying times, the atmospheric and moisture conditions of the soil were adequate for an appropriate functioning of the herbicide.

After the desiccation performed 60 DBSS, straw was collected (from $1 \mathrm{~m}^{2}$ per plot) seven times $(13,41$, $68,90,111,139$, and 177 days after desiccation-DAD); and straw was collected six times $(0,21,43,64,91$, and 129 DAD) after drying 15 days before sowing. The samples were placed in paper bags and dried to constant weight in a forced air circulation oven at $60^{\circ} \mathrm{C}$ and weighed.

To determine the $\mathrm{P}$ and $\mathrm{K}$ contents in the palisade straw, the collected samples were digested in a microwave (MARSXpress Model, CEM Corporation, Mathews, USA), using $6 \mathrm{~mL}$ of 1: 1 aqueous solution of nitric acid $\left(\mathrm{HNO}_{3}\right)$, and $2 \mathrm{~mL}$ hydrogen peroxide $\left(\mathrm{H}_{2} \mathrm{O}_{2}\right)$ at $130 \mathrm{~V}$. Leaf tissue of the palisade straw $(0.25 \mathrm{~g})$ was used and the volume completed to $30 \mathrm{~mL}$ (dilution 120x) for measurements, digested in a microwave oven at $1600 \mathrm{w}$ and cooled to room temperature for $20 \mathrm{~min}$. After, an analytical equipment with an inductively coupled plasma atomic emission spectrometer (ICP-OES Optima 8300 Dual View Model, PerkinElmer Corporation, São Paulo, Brazil) was used, for $\mathrm{P}$ and $\mathrm{K}$ contents determination. This equipment reads the samples simultaneously for all analytes and allows configurations for both axial and radial signal detection.

The $\mathrm{N}$ content in the palisade straw were determined by the Kjeldahl method with sulfuric digestion in a dry tube at $350^{\circ} \mathrm{C}$ for approximately 4 to $5 \mathrm{~h}$, with concentrated sulfuric acid $\left(\mathrm{H}_{2} \mathrm{SO}_{4}\right)$ and hydrogen peroxide $\left(\mathrm{H}_{2} \mathrm{O}_{2}\right)$; the samples were analyzed in an automatic distillation-titration system (AutoKjeldahl Unit K-370 Model, Buchi Corporation, New Casttle, USA).

The quantity of macronutrients in the straw was determined by the product of the dry weight by the nutrient content in the pasture residue. The nutrient release from straw to soil was calculated using the first derivative of the equations fitted to the data of accumulated nutrient (N, P, and K) release. Polynomial regression analysis was performed for the time after desiccation selecting the models (linear or quadratic) that best fit the data based on the $\mathrm{p}$-value and $\mathrm{r}^{2}$, using System for Analysis of Variance (Sisvar) software (Ferreira, 2011).

\section{Results and Discussion}

In the presence of nitrogen fertilization (both 150 and $300 \mathrm{~kg} \mathrm{ha}^{-1}$ rates), the pasture had produced a straw yield of about 5 to $6 \mathrm{Mg} \mathrm{ha}^{-1}$ until desiccation (both times) (Figure 1). The pattern of straw decomposition was similar in response to the three $\mathrm{N}$ rates, varying from 23 to $29 \mathrm{~kg} \mathrm{ha}^{-1}$ decomposed straw per day, with an approximate total of $2 \mathrm{Mg} \mathrm{ha}^{-1}$ at the end of the soybean cycle. This shows that Urochloa brizantha 'BRS Piatã' straw is highly persistent in the field. For an Urochloa ruziziensis pasture, maintained at three heights $(15,35$, and $50 \mathrm{~cm})$, grazed continuously for six months, Franchini et al. (2014) reported a dry weight of $4.1,6.8$, and $10.7 \mathrm{Mg} \mathrm{ha}^{-1}$, respectively.

In response to the three $\mathrm{N}$ fertilization rates and both desiccation times, the $\mathrm{N}$ content in palisade grass straw did not vary significantly during decomposition (Figure 2). However, the $\mathrm{N}$ straw contents differed significantly from the $\mathrm{N}$ rates of the pasture. At desiccation $60 \mathrm{DBS}$, the $\mathrm{N}$ contents were 7.0, 10.0, and $12.3 \mathrm{~g} \mathrm{~kg}^{-1}$ in the pasture treated with 0,150 , and $300 \mathrm{~kg} \mathrm{ha}^{-1} \mathrm{~N}$, respectively. When desiccating the pasture at $15 \mathrm{DBSS}$, the $\mathrm{N}$ contents of forage fertilized with 0,150 , and $300 \mathrm{~kg} \mathrm{ha}^{-1} \mathrm{~N}$, respectively, were 7.5 , 10.9 , and $12.2 \mathrm{~g} \mathrm{~kg}^{-1}$. The $\mathrm{N}$ contents found here were similar to those observed by Calonego et al. (2012), in a study in which $U$. brizantha initially contained $11.4 \mathrm{~g} \mathrm{~kg}^{-1}$ N. Similarly, Cavalli et al. (2018), found an initial content of $12.3 \mathrm{~g} \mathrm{~kg}^{-1} \mathrm{~N}$ in U. ruziziensis.

At the beginning of the evaluation period, the $\mathrm{N}$ straw content was higher after pasture fertilization with nitrogen (Figure 2), due to the higher concentration of this nutrient. Based on the adjusted models, the $\mathrm{N}$ straw content at $0 \mathrm{~N}$ fertilization and both drying times was $30-40 \mathrm{~kg} \mathrm{ha}^{-1}$, while after fertilization of the pasture with 150 and $300 \mathrm{~kg} \mathrm{ha}^{-1} \mathrm{~N}$, it rose to approximately $50 \mathrm{~kg} \mathrm{ha}^{-1}$. The daily rate of $\mathrm{N}$ release from pasture 
straw was higher after nitrogen fertilization. When desiccation was performed $60 \mathrm{DBSS}$, the daily $\mathrm{N}$ release rate varied from $0.07 \mathrm{~kg} \mathrm{ha}^{-1}$ without nitrogen fertilization to $0.23 \mathrm{~kg} \mathrm{ha}^{-1} \mathrm{~N}$ at the highest rate. At the desiccation $15 \mathrm{DBSS}$, the daily $\mathrm{N}$ release rate varied from $0.23 \mathrm{~kg} \mathrm{ha}^{-1}$ without $\mathrm{N}$ to $0.28 \mathrm{~kg} \mathrm{ha}^{-1}$ when fertilized with $150 \mathrm{~kg} \mathrm{ha}^{-1} \mathrm{~N}$. At the end of the evaluation period, the straw of the $\mathrm{N}$ fertilized pasture desiccated at 60 or 15 DBSS released about to 25 and $30 \mathrm{~kg} \mathrm{ha}^{-1}$ of $\mathrm{N}$ to soybean while the non-fertilized
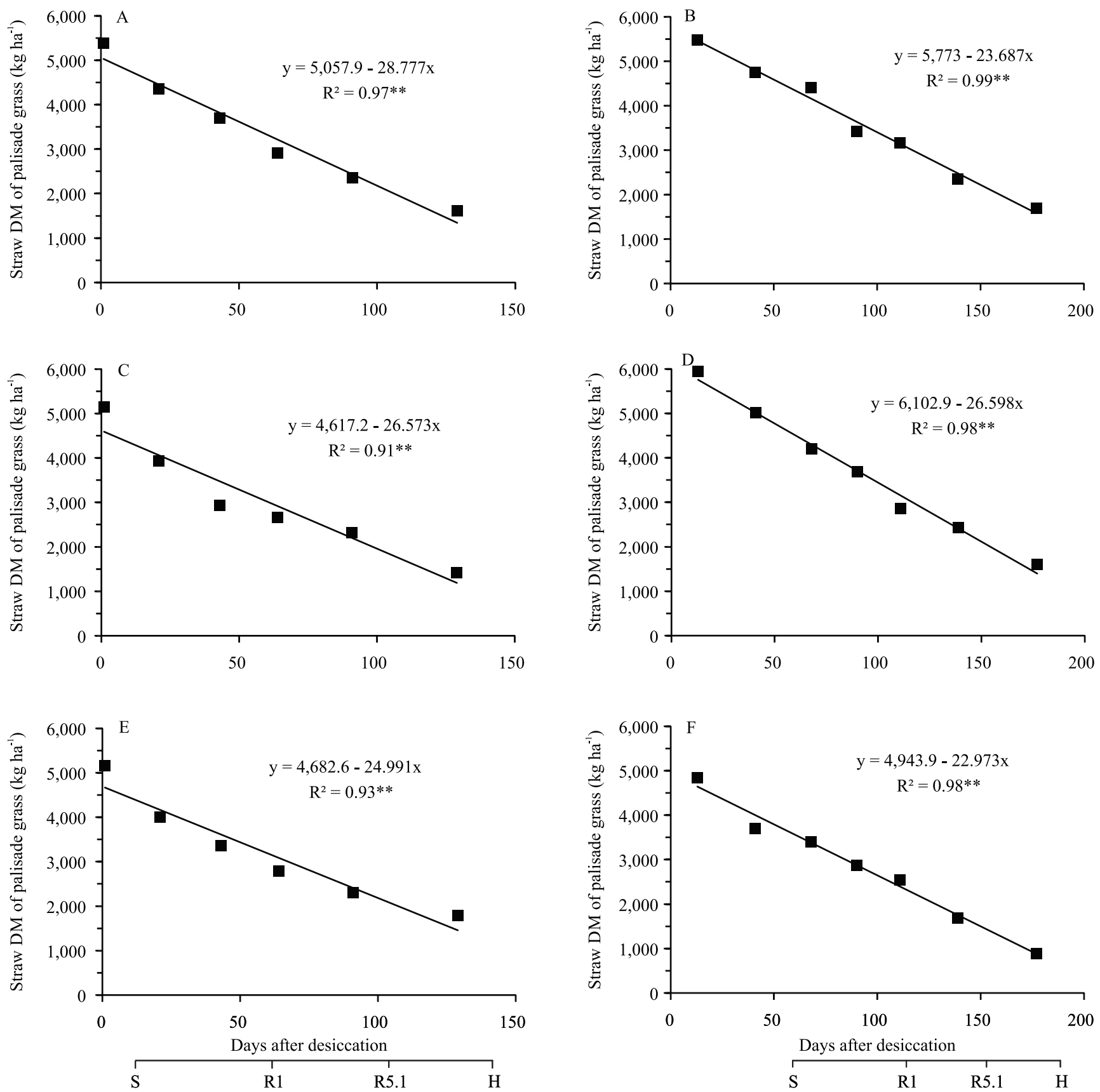

Figure 1. Dry matter (DM) of straw of palisade grass (Urochloa brizantha 'BRS Piatã') fertilized with three N rates: 0 (A, B); 150 (C, D) and $300 \mathrm{~kg} \mathrm{ha}^{-1} \mathrm{~N}(\mathrm{E}, \mathrm{F})$, according to time after desiccation, performed at 15 (A, C, E) and 60 (B, D, F) days before soybean (Glycine max 'BRS 1010 IPRO') sowing. S, soybean sowing; R1, beginning of soybean flowering; R5.1, beginning of grain filling; $\mathrm{H}$, soybean harvest. ** and *, significant at $1 \%$ and $5 \%$ probability, respectively, by regression analysis. 

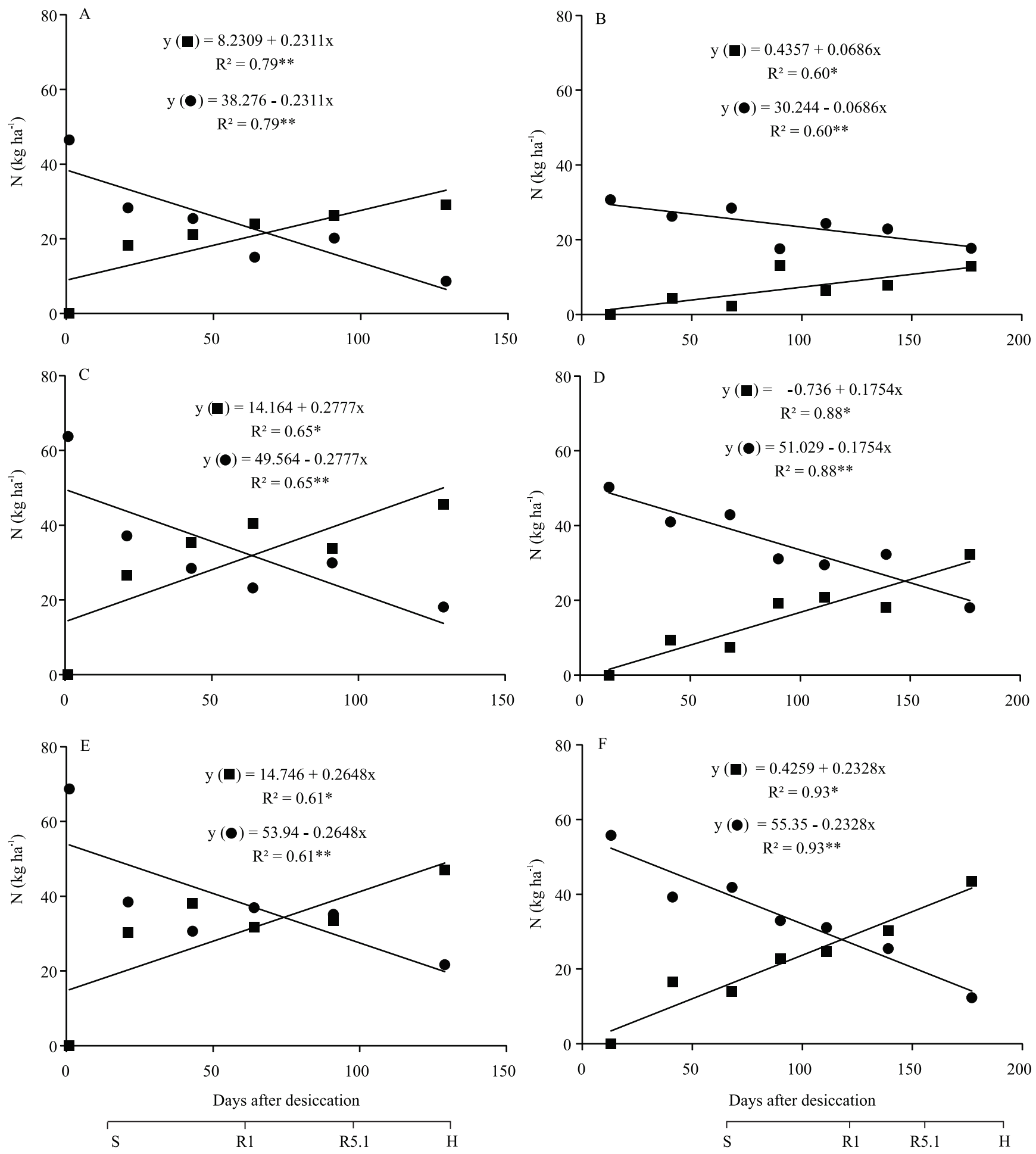

$\mathrm{N}$ in straw $\mathrm{N}$ release

Figure 2. Nitrogen $(\mathrm{N})$ quantity in straw and accumulated $\mathrm{N}$ release from straw of palisade grass (Urochloa brizantha 'BRS Piatã') fertilized with three $\mathrm{N}$ rates: 0 (A, B); 150 (C, D) and $300 \mathrm{~kg} \mathrm{ha}^{-1} \mathrm{~N}(\mathrm{E}, \mathrm{F})$, according to time after desiccation, performed at 15 (A, C, E) and 60 (B, D, F) days before soybean (Glycine max 'BRS 1010 IPRO') sowing. S, soybean sowing; $\mathrm{R} 1$, beginning of soybean flowering; R5.1, beginning of grain filling; $\mathrm{H}$, soybean harvest. ** and *, significant at $1 \%$ and $5 \%$ probability, respectively, by regression analysis. 
forage released about 8 and $25 \mathrm{~kg} \mathrm{ha}^{-1}$, respectively. These results demonstrate that in integrated systems, an adequate fertilization program for crops must be established since the absence of pasture fertilization limits N cycling (Costa et al., 2014).

It is worth mentioning that, despite the high amount of straw (about 5 to $6 \mathrm{Mg} \mathrm{ha}^{-1}$ ) produced by the pasture (Figure 1), the $\mathrm{N}$ quantity released for subsequent soybean was relatively low, due to the low straw nutrient contents (Figure 2). The $\mathrm{N}$ release rate is directly related to the release of $\mathrm{C}$, since the remaining $\mathrm{N}$ had the same performance pattern as the biomass contained in the system (Mendonça et al., 2015). Thus, in plant residues with a $\mathrm{C} / \mathrm{N}$ ratio higher than 25 , a strong temporary $\mathrm{N}$ immobilization and a relatively slow decomposition speed are usually observed (Calonego et al., 2012). Once $\mathrm{N}$ is fixed in organic compounds, it is available for cycling in the plant-straw-soil complex formed in agroecosystems (Xia et al., 2017). Consequently, the nitrogen returning to the soil contained in plant residues accounts for an important portion of the total $\mathrm{N}$ taken up by the subsequent crop (Costa et al., 2012).

The time when $50 \%$ of $\mathrm{N}$ was released from the straw - at the intersection point of the curves of $\mathrm{N}$ contained in the straw and the quantity released to the soil - varied from 65 to 150 days after pasture desiccation, and was not reached during the experimental period by straw of pasture without nitrogen fertilization, desiccated 60 days before sowing (Figure $2 \mathrm{~B}$ ). Similar results were described by Santos et al. (2014), in that the release of $50 \% \mathrm{~N}$ from $U$. ruziziensis was 128 days. On the other hand, Cavalli et al. (2018) reported a release time of half of the $\mathrm{N}$ contained in U. ruziziensis straw of 47 days. The slow $\mathrm{N}$ release from palisade grass straw can be a positive factor for the subsequent crop since, in this way, the nutrient can be better exploited by plants during the development cycle.

During decomposition, the straw $\mathrm{P}$ content tended to decrease (Figure 3). The P levels, with a quadratic performance, were similar in the straw of pasture fertilized with the three $\mathrm{N}$ rates and at both desiccation times, indicating that $\mathrm{N}$ fertilization of palisade grass did not significantly influence the $\mathrm{P}$ levels in the residual straw. For marandu grass, Primavesi et al. (2006) observed that the P levels did not increase when fertilized with $\mathrm{N}$ in the form of ammonium nitrate but decreased after $\mathrm{N}$ applied in the form of urea. No significant differences in the P contents of $U$. brizantha 'Xaraés' straw were observed by Costa et al. (2014) in response to five $\mathrm{N}$ rates $(0,50,100,150$, and 200 $\mathrm{kg} \mathrm{ha}^{-1} \mathrm{~N}$ ), corroborating the data of this study.

The dynamics of $\mathrm{P}$ release from palisade grass straw was similar in response to the three $\mathrm{N}$ fertilization rates (Figure 3). The total amount released by the pasture ranged from 6 to $10 \mathrm{~kg} \mathrm{ha}^{-1} \mathrm{P}_{2} \mathrm{O}_{5}$. These values are low compared to the demand of a subsequent soybean crop, by which around $10 \mathrm{~kg} \mathrm{P}_{2} \mathrm{O}_{5}$ are exported per ton of grain (Tecnologias..., 2013). However, this study indicates that the amounts of $\mathrm{P}$ supplied via residual straw of $U$. brizantha 'BRS Piatã' are rather low. On the other hand, it should be mentioned that the amount of $\mathrm{P}$ cycled through the biomass grazed by cattle was not evaluated. The selection of plant species with high efficiency in accumulating $\mathrm{P}$ in the plant shoots and subsequent release to the soil by the mineralization of organic compounds is a useful strategy to increase $\mathrm{P}$ availability for the plants since this element can undergo changes by the fixation process and be transformed into non-labile forms in the soil (Costa et al., 2012).

The potential amount of $\mathrm{P}$ to be released from organic tissues are usually structurally linked to protein molecules and compounds responsible for energy transport, making it available both for root uptake of the subsequent crop and for immobilization in mineral constituents with complex solubility (Mendonça et al., 2015). As also observed in this study for the remaining amount of $\mathrm{P}$ in plant residues, Rossi et al. (2013) reported an initial phase of rapid P release followed by a slower one. Practically all P contained in the straw was released to the subsequent soybean, and the period to release $50 \%$ of the P from the straw lasted 30 to 65 days. Santos et al. (2014) observed that it took 67 days to release half of the P contained in U. ruziziensis straw.

The $\mathrm{K}$ contents decreased rapidly in the first days after desiccation, in the straw of pasture treated with three $\mathrm{N}$ fertilization rates and desiccation after two periods (Figure 4). The cation $\mathrm{K}$ is mostly concentrated in the cytoplasm of plant cells and has no structural function, but forms bonds with easily reversible organic complexes, and is therefore easily disassociated from the remaining plant material (Mendonça et al., 2015). Consequently, shortly after pasture desiccation, the tissue concentration of this

Pesq. agropec. bras., Brasília, v.55, e01853, 2020

DOI: 10.1590/S1678-3921.pab2020.v55.01853 

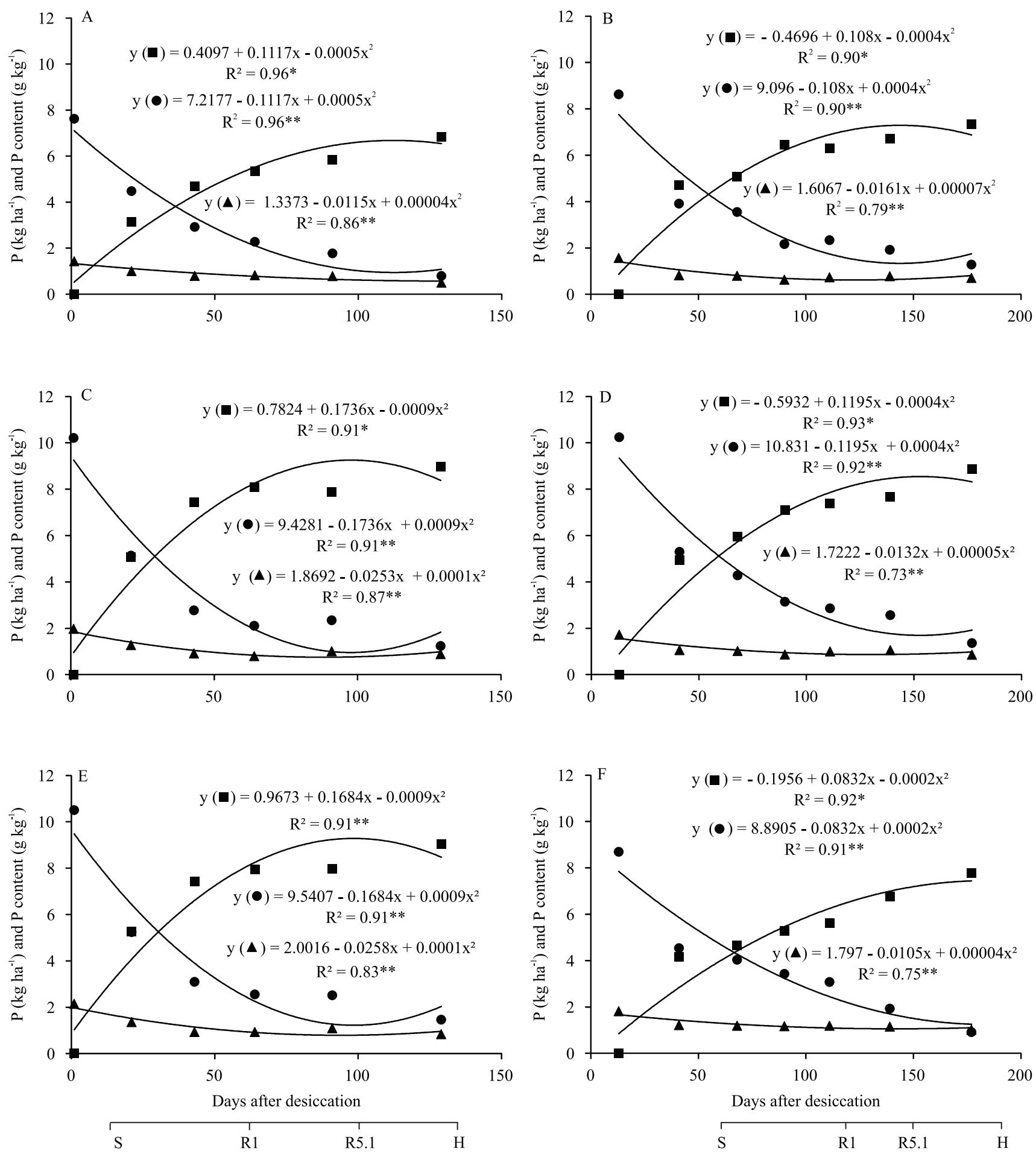

\section{- P in straw $\boldsymbol{D}$ release $\boldsymbol{\Delta} \mathrm{P}$ content}

Figure 3. Phosphorus $(\mathrm{P})$ content, quantity in straw and accumulated release from straw of palisade grass (Urochloa brizantha 'BRS Piatã') fertilized with three $\mathrm{N}$ rates: 0 (A, B); 150 (C, D), and $300 \mathrm{~kg} \mathrm{ha}^{-1} \mathrm{~N}(\mathrm{E}, \mathrm{F})$, according to time after desiccation, performed at 15 (A, C, E) and 60 (B, D, F) days before soybean (Glycine max 'BRS 1010 IPRO') sowing. S, soybean sowing; R1, beginning of soybean flowering; R5.1, beginning of grain filling; H, soybean harvest. ** and *, significant at $1 \%$ and $5 \%$ probability, respectively, by regression analysis. 

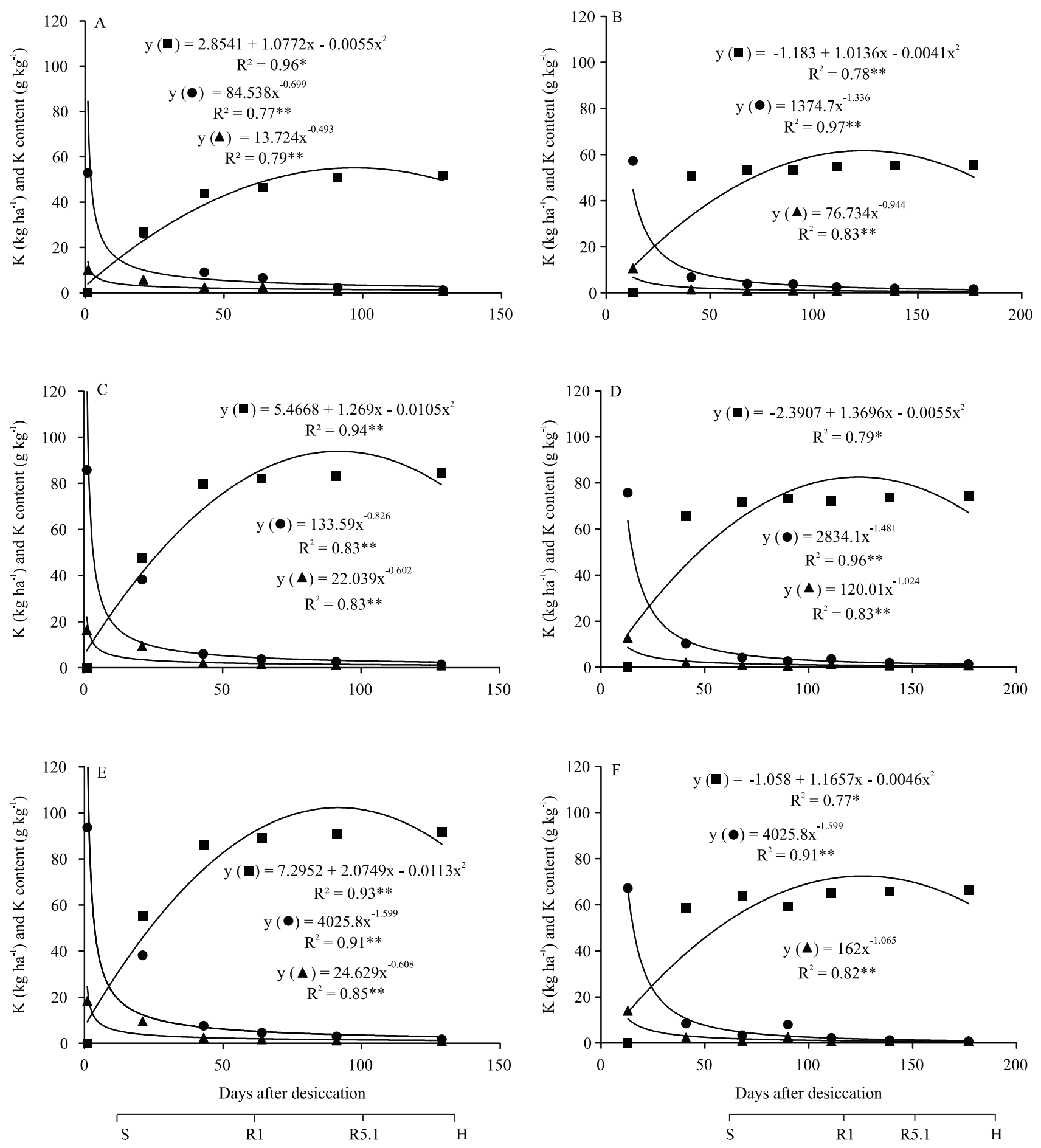

- $\mathrm{K}$ in straw $\mathrm{K}$ release $\Delta \mathrm{K}$ content

Figure 4. Potassium (K) content, quantity in straw and accumulated release from straw of palisade grass (Urochloa brizantha 'BRS Piatã') fertilized with three $\mathrm{N}$ rates: 0 (A, B), 150 (C, D), and $300 \mathrm{~kg} \mathrm{ha}^{-1} \mathrm{~N}(\mathrm{E}, \mathrm{F})$, according to time after desiccation, performed at 15 (A, C, E) and 60 (B, D, F) days before soybean (Glycine max 'BRS 1010 IPRO') sowing. S, soybean sowing; $\mathrm{R} 1$, beginning of soybean flowering; R5.1, beginning of grain filling; $\mathrm{H}$, soybean harvest. ** and *, significant at $1 \%$ and $5 \%$ probability, respectively, by regression analysis. 
nutrient decreased markedly, because after the rupture of the plasma membranes it was rapidly carried away by rainwater (Crusciol et al., 2008).

It is important to highlight that $\mathrm{N}$ fertilization of the pasture induced a significant increase in the $\mathrm{K}$ straw content, indicating that $\mathrm{N}$ application can favor $\mathrm{K}$ cycling in palisade grass. In a study with $U$. brizantha 'Xaraés', Costa et al. (2008) confirmed these data since the $\mathrm{K}$ straw content tends to a quadratic increase in response to increasing $\mathrm{N}$ rates. Similarly, Primavesi et al. (2006) also observed an increase in $\mathrm{K}$ levels in $U$. brizantha 'Marandu' pasture under increasing $\mathrm{N}$ rates.

The amount of $\mathrm{K}$ released from the straw was high, especially when the pasture had received nitrogen fertilization (Figure 4). In the desiccation carried out 60 DBSS, the amount of $\mathrm{K}$ released from the straw of unfertilized pasture was $60 \mathrm{~kg} \mathrm{ha}^{-1}$ (Figure $4 \mathrm{~B}$ ), but $80 \mathrm{~kg} \mathrm{ha}^{-1}$ from the straw of pasture fertilized with 150 $\mathrm{kg} \mathrm{ha}^{-1} \mathrm{~N}$ (Figure $4 \mathrm{D}$ ). The export per ton of grain of this nutrient by soybean is approximately $20 \mathrm{~kg} \mathrm{~K}_{2} \mathrm{O}$ (Tecnologias..., 2013). Therefore, for a production of four tons of grain, the $\mathrm{K}$ released from the straw of $\mathrm{N}$-fertilized pasture would be sufficient to offset the export in soybean, in case of no erosion or leaching losses in the system.

At desiccation 15 DBSS, the accumulated amount of $\mathrm{K}$ released from the unfertilized dry pasture was 60 $\mathrm{kg} \mathrm{ha}^{-1}$ (Figure $4 \mathrm{~A}$ ), and $100 \mathrm{~kg} \mathrm{ha}^{-1}$ from the straw of the pasture fertilized with $300 \mathrm{~kg} \mathrm{ha}^{-1} \mathrm{~N}$ (Figure $4 \mathrm{E}$ ). These results indicate the effect of pasture $\mathrm{N}$ fertilization to intensify $\mathrm{K}$ cycling in palisade grass. Also, a probable explanation for the increase of $\mathrm{K}$ accumulation in palisade grass straw after nitrogen fertilization is the intensified root growth of the forage, increasing $\mathrm{K}$ uptake. It is worth remembering that a more developed root system has a greater exploration capacity of the soil profile, which improves the facility of taking up higher nutrient amounts, even at a depth below $0.2 \mathrm{~m}$. The growth of the root system of forage grasses is fast and deep, which may have resulted in the uptake of $\mathrm{K}$ leached into subsurface layers (Mendonça et al., 2015; Galindo et al., 2018).

The time to release $50 \%$ of the $\mathrm{K}$ contained in the straw was 10-20 days. A very early pasture desiccation can reduce the exploitation of $\mathrm{K}$ by subsequent soybean, due to the rapid release of this nutrient. For this reason, the best way to supply soybean with $\mathrm{K}$ released from the straw is to dry the grass shortly before sowing. The time required to release half of the $\mathrm{K}$ content reported by Cavalli et al. (2018) was 16 days for palisade grass. According to Santos et al. (2014), it took only 13 days to release $50 \% \mathrm{~K}$.

In general, the nutrient contents released from palisade grass straw followed the following order: $\mathrm{K}>\mathrm{N}>\mathrm{P}$, regardless of $\mathrm{N}$ application to the pasture or desiccation time. The quantities of $\mathrm{K}, \mathrm{N}$, and $\mathrm{P}$ released by $U$. brizantha straw fertilized with $300 \mathrm{~kg}$ ha $^{-1} \mathrm{~N}$ can offset $80,15.7$ and $18 \%$, respectively, of the $\mathrm{N}$ exported via soybean in a grain yield of $5 \mathrm{Mg} \mathrm{ha}^{-1}$, considering zero losses in the system. In this context, the $\mathrm{K}$ released from $U$. brizantha straw is essential for oilseed nutrition, and studies are needed to test the possibility of reducing the $\mathrm{K}$ rate applied to soybean grown after pasture species of the genus Urochloa.

\section{Conclusions}

1. Nitrogen fertilization of Urochloa brizantha 'BRS Piatã' significantly increases $\mathrm{N}$ and $\mathrm{K}$ cycling and the release of these nutrients to subsequent soybean (Glycine max).

2. The amount of $\mathrm{K}$ released from $U$. brizantha straw fertilized with 150 or $300 \mathrm{~kg} \mathrm{ha}^{-1} \mathrm{~N}$ is sufficient to offset the export in up to $4,000 \mathrm{~kg} \mathrm{ha}^{-1}$ of soybean grains.

3. Early desiccation of $U$. brizantha pasture ( 60 days before soybean sowing) can disadvantage the K use by soybean since $50 \%$ of the nutrient is released in the first 20 days after desiccation.

4. The dynamics of $\mathrm{P}$ release from $U$. brizantha straw is not influenced by nitrogen fertilization and desiccation time.

\section{Acknowledgments}

To Conselho Nacional de Desenvolvimento Científico e Tecnológico (CNPq) and to Coordenação de Aperfeiçoamento de Pessoal de Nível Superior (Capes), for the doctoral scholarships granted to the first and second authors; to CNPq, for granting to the third author a scholarship for Productivity in Technological Development and Innovative Extension; and to Agrisus foundation, for financial support (Project 2180/17). 


\section{References}

CALONEGO, J.C.; GIL, F.C.; ROCCO, V.F.; SANTOS, E.A. dos. Persistência e liberação de nutrientes da palha de milho, braquiária e labe-labe. Bioscience Journal, v.28, p.770-781, 2012.

CAVAlli, E.; LANGE, A.; CAVAlli, C.; BEHling, M. Decomposition and release of nutrients from crop residues on soybean-maize cropping systems. Revista Brasileira de Ciências Agrárias, v.13, e5527, 2018. DOI: https://doi.org/10.5039/agraria. v13i2a5527.

COSTA, K.A. de P.; OLIVEIRA, I.P. de; FAQUIN, V.; FIGUEIREDO, F.C.; RODRIGUES, C. R.; NASCIMENTO, P.P. Adubação nitrogenada e potássica na concentração de nutrientes do capim-xaraés. Ciência Animal Brasileira, v.9, p.86-92, 2008.

COSTA, N.R.; ANDREOTTI, M.; BUZETTI, S.; LOPES, K.S.M.; SANTOS, F.G. dos; PARIZ, C.M. Acúmulo de macronutrientes e decomposição da palhada de braquiárias em razão da adubação nitrogenada durante e após o consórcio com a cultura do milho. Revista Brasileira de Ciências do Solo, v.38, p.1223-1233, 2014. DOI: https://doi.org/10.1590/S0100-06832014000400019.

COSTA, N.R.; ANDREOTTI, M.; GAMEIRO, R. de A.; PARIZ, C.M.; BUZETTI, S.; LOPES, K.S.M. Adubação nitrogenada no consórcio de milho com duas espécies de braquiária em sistema plantio direto. Pesquisa Agropecuária Brasileira, v.47, p.1038-1047, 2012. DOI: https://doi.org/10.1590/S0100$204 X 2012000800003$.

COSTA, N.R.; ANDREOTTI, M.; ULIAN, N. de A.; COSTA, B.S.; PARIZ, C.M.; TEIXEIRA FILHO, M.C.M. Acúmulo de nutrientes e tempo de decomposição da palhada de espécies forrageiras em função de épocas de semeadura. Bioscience Journal, v.31, p.818-829, 2015. DOI: https://doi.org/10.14393/BJv31n3a2015-22434.

CRUSCIOL, C.A.C.; MORO, E.; LIMA, E. do V.; ANDREOTTI, M. Taxas de decomposição e de liberação de macronutrientes da palhada de aveia preta em plantio direto. Bragantia, v.67, p.481-489, 2008. DOI: https://doi.org/10.1590/S000687052008000200024 .

FERREIRA, D.F. Sisvar: a computer statistical analysis system. Ciência e Agrotecnologia, v.35, p.1039-1042, 2011. DOI: https://doi.org/10.1590/S1413-70542011000600001.

FRANCHINI, J.C.; BALBINOT JUNIOR, A.A.; DEBIASI, H.; CONTE, O. Soybean performance as affected by desiccation time of Urochloa ruziziensis and grazing pressures. Revista Ciência Agronômica, v.45, p.999-1005, 2014. DOI: https://doi.org/10.1590/S1806-66902014000500015.

GALINDO, F.S.; BUZETTI, S.; TEIXEIRA FILHO, M.C.M.; DUPAS, E.; LUDKIEWICZ, M.G.Z. Acúmulo de matéria seca e nutrientes no capim-mombaça em função do manejo da adubação nitrogenada. Revista de Agricultura Neotropical, v.5, p.1-9, 2018. DOI: https://doi.org/10.32404/rean.v5i3.2132.
MATEUS, G.P.; CRUSCIOL, C.A.C.; BORGHI, E.; PARIZ, C.M.; COSTA, C.; SILVEIRA, J.P.F. da. Adubação nitrogenada de sorgo granífero consorciado com capim em sistema de plantio direto. Pesquisa Agropecuária Brasileira, v.46, p.1161-1169, 2011. DOI: https://doi.org/10.1590/S0100-204X2011001000007.

MENDONÇA, V.Z. de; MELLO, L.M.M. de; ANDREOTTI, M.; PARIZ, C.M.; YANO, E.H.; PEREIRA, F.C.B.L. Liberação de nutrientes da palhada de forrageiras consorciadas com milho e sucessão com soja. Revista Brasileira de Ciências do Solo, v.39, p.183-193, 2015. DOI: https://doi.org/10.1590/01000683rbcs20150666.

PRIMAVESI, A.C.; PRIMAVESI, O.; CORRÊA, L. de A.; SILVA, A.G. da; CANTARELLA, H. Nutrientes na fitomassa de capim-marandu em função de fontes e doses de nitrogênio. Ciência e Agrotecnologia, v.30, p.562-568, 2006. DOI: https://doi.org/10.1590/S1413-70542006000300024.

ROSSI, C.Q.; PEREIRA, M.G.; GIÁCOMO, S.G.; BETTA, M.; POLIDORO, J.C. Decomposição e liberação de nutrientes da palhada de braquiária, sorgo e soja em áreas de plantio direto no cerrado goiano. Semina: Ciências Agrárias, v.34, p.1523-1534, 2013. DOI: https://doi.org/10.5433/1679-0359.2013v34n4p1523.

SALTON, J.C.; MERCANTE, F.M.; TOMAZI, M.; ZANATTA, J.A.; CONCENÇO, G.; SILVA, W.M.; RETORE, M. Integrated crop-livestock system in tropical Brazil: toward a sustainable production system. Agriculture, Ecosystems and Environment, v.190, p.70-79, 2014. DOI: https://doi.org/10.1016/j. agee.2013.09.023.

SANTOS, F.C. dos; ALBUQUERQUE FILHO, M.R. de; VILELA, L.; FERREIRA, G.B.; CARVALHO, M. da C.S.; VIANA, J.H.M. Decomposição e liberação de macronutrientes da palhada de milho e braquiária, sob integração lavoura-pecuária no cerrado baiano. Revista Brasileira de Ciências do Solo, v.38, p.1855-1861, 2014. DOI: https://doi.org/10.1590/S0100-06832014000600020.

SANTOS, H.G. dos; JACOMINE, P.K.T.; ANJOS, L.H.C. dos; OLIVEIRA, V.Á. de; LUMBRERAS, J.F.; COELHO, M.R.; ALMEIDA, J.A. de; ARAÚJO FILHO, J.C. de; OLIVEIRA, J.B. de; CUNHA, T.J.F. Sistema brasileiro de classificação de solos. 5.ed. rev. e ampl. Brasília: Embrapa, 2018.

SOIL SURVEY STAFF. Keys to soil taxonomy. $12^{\text {th }}$ ed. Washington: USDA, 2014.

TECNOLOGIAS de produção de soja: Região Central do Brasil 2014. Londrina: Embrapa Soja, 2013. 265p. (Embrapa Soja. Sistemas de produção, 16).

XIA, L.; LAM, S.K.; YAN, X.; CHEN, D. How does recycling of livestock manure in agroecosystems affect crop productivity, reactive nitrogen losses, and soil carbon balance? Environmental Science \& Technology, v.51, p.7450-7457, 2017. DOI: https://doi.org/10.1021/acs.est.6b06470. 